\title{
OYSTER SPAT RECRUITMENT IN ESPÍRITO SANTO STATE, BRAZIL, USING RECYCLED MATERIALS
}

\author{
Rosebel C. Nalesso*, Karla Paresque ${ }^{I}$, Prússia P. Piumbini, João Filipe R. Tonini ${ }^{l}$, Lorena G. Almeida and \\ Vanessa M. Níckel \\ Universidade Federal do Espírito Santo \\ Departamento de Ecologia e Recursos Naturais - CCHN - Laboratório de Bentologia \\ (Av. Fernando Ferrari, 514, 29075-910 Vitória, ES, Brasil) \\ ${ }^{1}$ PIBIC-UFES \\ *corresponding author: rosebel.nalesso@terra.com.br
}

\begin{abstract}
A B S T R A C T
This paper evaluated the effectiveness of four types of oyster spat collectors, made with recycled materials, in the recruitment of the mangrove oyster Crassostrea spp. at five sites in the Benevente river estuary, Anchieta District and on two islands in Piúma District, both in Espírito Santo State. The collectors were made of: 1- oyster shells, 2- PET bottles, 3- car tires and 4- tiles, all of them suspended by ropes and tied to roots of Rhizophora mangle or mussel long-lines. The number of spat recruited on each collector and their shell lengths were registered bimonthly, as well as the physicochemical-trophic parameters of the water: salinity, temperature, dissolved oxygen, particulate organic matter and chlorophyll $a$, which were correlated (by Spearman's correlation) with the number of spat recruited. Spat settlement was significantly higher on oyster shell, tile and tire collectors, mainly at points with higher salinities, such as Praia do Coqueiro in Anchieta and on Meio and Cabrito Islands in Piúma (Kruskal-Wallis: $\mathrm{H}=10.01 ; 3$ d.f.; $\mathrm{p}<0.05$ ). Oyster spat recruitment occurred throughout the year, being higher from November to February, but because of losses due to storms or theft, the difference was not statistically significant (Kruskal-Wallis: $\mathrm{H}=1.42 ; 7$ d.f.; $\mathrm{p}>0.05$ ). The number of oyster spat was positively correlated with the salinity $\left(\rho_{\mathrm{s}}=0.331 ; \mathrm{p}<0.05\right)$ and water temperature $\left(\rho_{\mathrm{s}}=0.48 ; \mathrm{p}<0.05\right)$, revealing that areas with higher salinities and summer months were better for spat collection.
\end{abstract}

\section{RESUMO}

Este trabalho avaliou a eficiência de quatro tipos de coletores de sementes no recrutamento de ostras Crassostrea sp., em cinco pontos do estuário do Rio Benevente, município de Anchieta, e em duas ilhas no município de Piúma, estado do Espírito Santo. Foram utilizados quatro tipos de coletores: 1conchas de ostras, 2- garrafas PET, 3-tiras de pneu e 4- telhas, todos suspensos por cordas e amarrados em rizóforos de Rhizophora mangle ou em "long-lines" de mexilhões. Bimensalmente, as sementes recrutadas foram contadas e medidas quanto à altura, determinando-se os parâmetros físicoquímicos-tróficos da água: salinidade, temperatura, oxigênio dissolvido, matéria orgânica particulada e clorofila- $a$, que foram correlacionados com o número de sementes nos coletores (através de correlações de Spearman). O recrutamento de sementes foi significativamente maior nos coletores de conchas de ostras, telhas e pneus, principalmente nos pontos de salinidade mais alta (Praia do Coqueiro em Anchieta e Ilhas do Meio e do Cabrito em Piúma) (Kruskal-Wallis: H= 10,01; 3 g.l.; $P$ $<0,05)$. A fixação de sementes ocorreu durante todo o ano, sendo mais alta de novembro a fevereiro; porém, devido ao alto número de coletores perdidos por roubo ou tempestades, esta diferença não foi significativa (Kruskal-Wallis: $\mathrm{H}=1,42 ; 7$ g.l.; $P>0,05$ ). $\mathrm{O}$ número de sementes de ostras foi positivamente correlacionado com a salinidade $\left(\rho_{\mathrm{s}}=0,331 ; P<0,05\right)$ e temperatura da água $\left(\rho_{\mathrm{s}}=0,48\right.$; $P<0,05)$, indicando que os locais de salinidades mais altas e os meses de verão são os melhores para se coletar sementes de ostras.

Descriptors: Mangrove oyster; Crassostrea spp.; Benevente river estuary; Piúma Islands; Espírito Santo- Brazil.

Descritores: Ostra do mangue; Crassostrea spp.; Estuário do Rio Benevente-Anchieta; Ilhas de Piúma; Espírito Santo-Brasil. 


\section{INTRODUCTION}

The oyster spat is a crucial step in successful commercial oyster farming. The collection of spat in nature, without laboratory costs, is a positive factor in mariculture, reducing costs and enhancing the farmers' profits (HICKMAN, 1992); however, frequently natural stocks of oyster spat are insufficient to meet farming demands. But presently in Brazil there are only two hatcheries in the southern region, and costs could be a constraint to small farmers, since remote settling is available only to major farmers. MIRANDA and GUZENSKI (1999) have suggested that recruitment in natural habitats should be investigated before any investment is made in hatcheries.

The collection of oyster spat in natural habitats has been successful, and many important producers, such as the French ones, rely almost exclusively on oyster spat from the natural environment (ROBERT; GÉRARD, 1999). Many different materials may be employed: mangrove roots or branches (WELDER, 1980), tiles (JOSEPH; JOSEPH, 1983; SATYANARAYANA, 1983), fibreglass and resin (MONTOYA; MADRIZ, 1986), oyster shells (PEREIRA; AKABOSHI; SOARES, 1988), fiber-cement covered with cement and lime (BUITRAGO; LUNAR; MORENO, 2002), plastic sheeting (DEVAKIE; ALI, 2002) and PET bottles (BEZERRA; FRAGA; SILVA, 2003; BUITRAGO; ALVARADO, 2005), among others. In Korea, spat are also culled from natural habitats, chosen for their gently sloping grounds and estuarine silt mixed with sand, with no great variation in salinity values, and subject to little wave influence, but with wind blowing towards the collecting sites (PARK et al., 1988).

The mangrove oyster, Crassostrea rhizophorae, is typical of tropical areas, occurring mainly on aerial roots of the red mangrove, Rhizophora mangle or on intertidal rocky shores (NASCIMENTO, 1982). There is much controversy about the genus in Brazil: PEREIRA; AKABOSHI; SOARES (1988) and NASCIMENTO (1991) recognised that Crassostrea brasiliana is distinct from C. rhizophorae, because the former is larger and is always found in subtidal mangrove channels, whilst the latter is smaller and inhabits intertidal zones. RIOS (1994) considered $C$. brasiliana a synonym of $C$. rhizophorae. IGNACIO et al. (2000), through allozyme electrophoresis, found that even sympatric populations of the two forms of Crassostrea were different enough to be considered distinct species, though populations of $C$. rhizophorae collected from distant locations were found to be very similar.

This study seeks to evaluate the technical viability of the recruitment of spat of Crassostrea spp. utilizing recycled materials of low cost, at different sites on natural oyster banks in the Benevente river estuary, Anchieta District and on Cabritos and Meio islands, Piúma District, in Espírito Santo State, southeastern Brazil. To avoid mistakes and due to the small size of the spat, both species will be considered as Crassostrea spp.

\section{Material and Methods}

Study Area

The study was undertaken in the Benevente River estuary and its tributary Arerá river, in the Anchieta District $\left(20^{\circ} 48^{\prime} \mathrm{S} ; 40^{\circ} 39^{\prime} \mathrm{W}\right)$, south-eastern Brazil, both with luxuriant mangrove forest, adjacent to the most important mussel farming area of the state, located on the Coqueiro Beach. The average depth of the water is $3 \mathrm{~m}$ and tidal currents may reach $25 \mathrm{~cm} . \mathrm{s}^{-1}$ in winter and $35 \mathrm{~cm} \cdot \mathrm{s}^{-1}$ in summer, predominantly in a south-westerly direction (Fig. 1). Five sites were chosen within this estuarine area, two of them in the Arerá River (P1 and P2), two others in the Benevente River (P3 and P4) and the fifth in the mussel farming area of the Coqueiro Beach (P5). Adult oysters were found at all these sites, so their larvae would be able to settle on the collectors.

The other two points were located in the Piúma District $\left(20^{\circ} 50^{\prime} \mathrm{S} ; 40^{\circ} 43^{\prime} \mathrm{W}\right)$, adjacent to Iconha river, with small mangrove clumps, but important sources of spat. The collectors were tied to a raft off Meio Island (P6) and to a mussel farming long-line off Cabrito Island (P7), both having natural oyster banks, mainly at P6, probably due to weak hydrodynamic activity and shallow depth (1.5m at low tide), which enhance oyster settlement (ABSHER, 1987; BAKER, 1997).

\section{Physico-chemical-trophic parameters of the Water}

The salinity and temperature of and the dissolved oxygen in the water next to the collectors were recorded in situ, using a multiparameter device (YSI 85) during oyster spat sampling, whilst the trophic parameters such as chlorophyll $a$ and particulate organic matter in the water were carried out back in the laboratory, by filtering $200 \mathrm{ml}$ of water through fiberglass filters. Chlorophyll $a$ was extracted (after freezing the filters at $-20^{\circ} \mathrm{C}$ ) with acetone $90 \%$ and determined by spectrophotometer absorbance (JEFFREY; HUMPHREY, 1975); the organic matter was assessed by the difference in filter weight (after burning the filters in a furnace at $450^{\circ} \mathrm{C}$ for 2 hours). 
Spat Collectors and Sampling

Four different types of collectors were utilized: 1-oyster shells: ten oyster shells were drilled centrally and hung on a string; 2- PET bottles: ten half PET bottles, $3 \mathrm{~cm}$ apart, were hung on a string; 3 - car tires: ten pieces of car tire $( \pm 10 \times 25 \mathrm{~cm})$ were also drilled centrally and hung on a string, $2 \mathrm{~cm}$ apart; 4tiles: 3 clay tiles $(30 \times 35 \mathrm{~cm})$ were tied together with string and hung on a rope. All the collectors were suspended from ropes (of about $1 \mathrm{~m}$ length) and tied to roots of Rhizophora mangle (at P1 to P4), to a raft (P6) or to mussel long-lines (P5 and P7). Three collectors of each type were set at each point, in June/2004.

Bimonthly, from August/2004 to August/2005 and quarterly (due to logistic constrains) from November/2005 to February/2006, during low tides, the collectors with oyster spat were withdrawn, and replaced with new ones. The number of spat recruited on each collector was counted and calculated per area of each type of collector. The spat shell height of a sample of a hundred spat, from each collector and site, were measured with a Vernier calliper. The number of oyster spat on each type of collector, by site and month, was compared by the non-parametric tests: Kruskal-Wallis and Nemenyi tests (ZAR, 1999), due to the heteroscedasticity of data, even after transformation.

The physico-chemical-trophic parameters of the water were correlated (by Spearman's correlation) with the number of spat recruited at each site.

\section{Results}

Physico-chemical-trophic Parameters of the Water

At the estuarine sites (P1 to P4) water salinity was usually around $5 \%$ at low tide, with higher values at P5 to P7 and more stable ones at P6 and P7 (around $35 \%$ ) (Fig. 2) due to their respective distances from the sea. The temperature was the least variable parameter among the sites, ranging from 21.6 to $29.7^{\circ} \mathrm{C}$ along the year, with slightly higher values at the estuarine sites. Dissolved oxygen was lower at the estuarine sites, particularly at P1, with values always below $5 \mathrm{mg} . \mathrm{L}^{-1}$, whilst at the other sites they were higher (Fig. 2). Particulate organic matter was the most variable parameter, both among sites as well as months, ranging from 0 to $20.5 \mathrm{mg} . \mathrm{L}^{-1}$, being higher during the winter period (from June to September) at all the sites. Chlorophyll $a$ varied from 0 to $6 \mu \mathrm{g} . \mathrm{L}^{-1}$, except at P1, where $10 \mu \mathrm{g} . \mathrm{L}^{-1}$ was recorded during autumn and winter (Fig. 2).

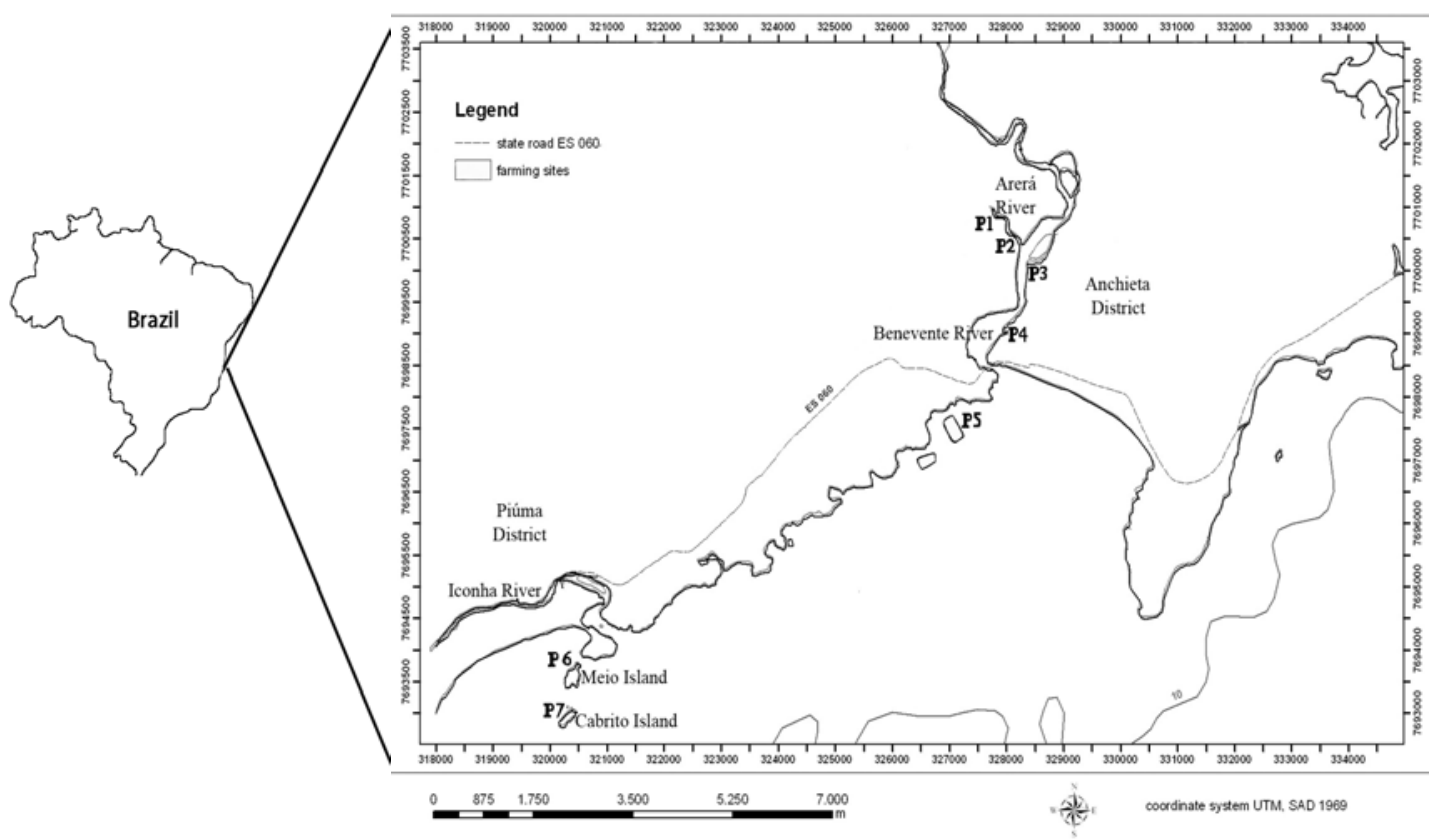

Fig. 1. Geographic location of sampling sites at Anchieta and Piúma District. 


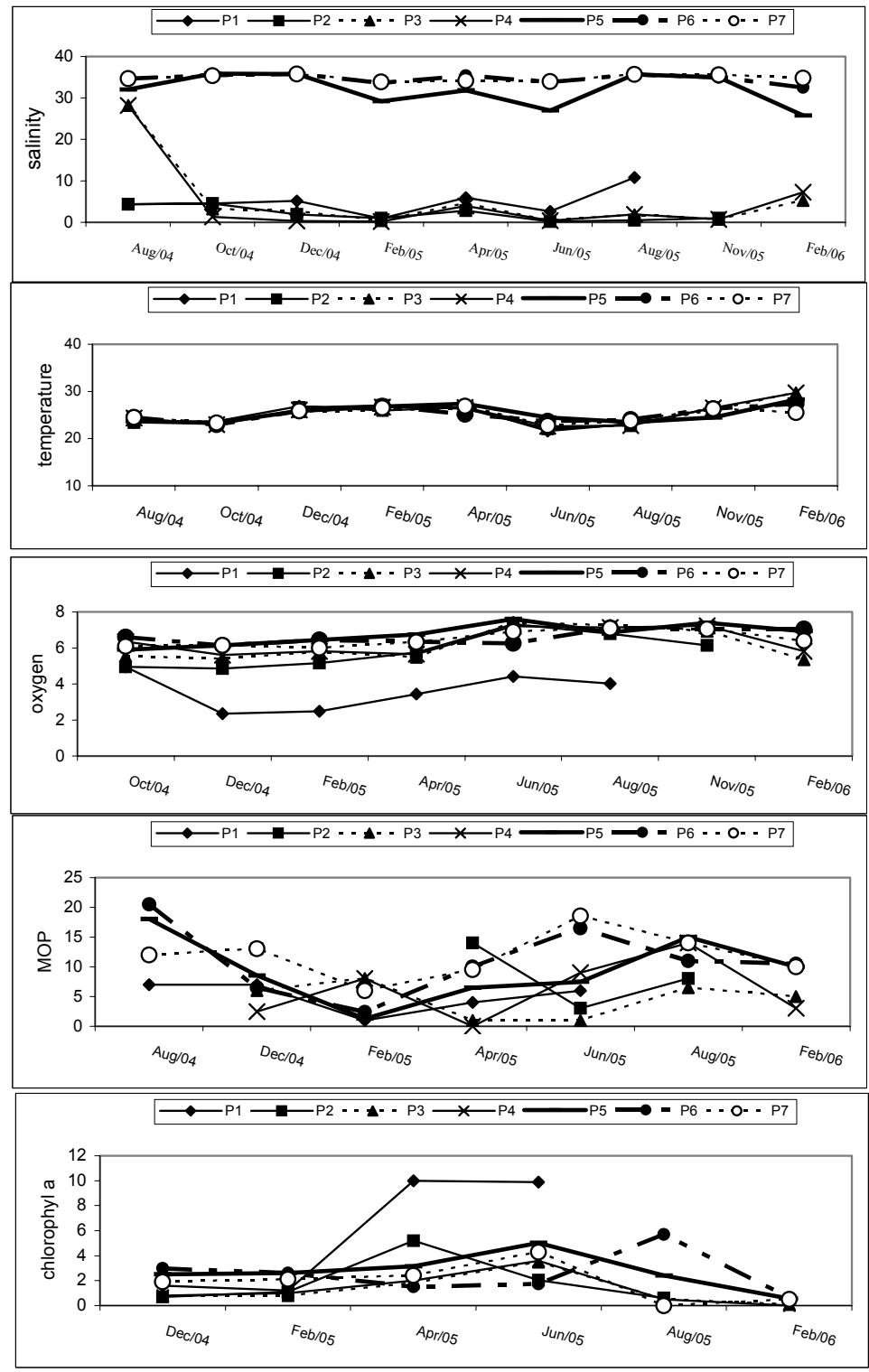

Fig. 2. Physico-chemical-trophic parameters of water at sampling sites at Benevente river estuary (P1 to P5) and Piúma islands (P6 and P7): salinity (\%o), temperature $\left({ }^{\circ} \mathrm{C}\right)$, dissolved oxygen $\left(\mathrm{mg} . \mathrm{L}^{-1}\right)$, particulate organic matter (POM, mg. $\mathrm{L}^{-1}$ ) and chlorophyll $a\left(\mu \mathrm{g} . \mathrm{L}^{-1}\right)$. 
Spat on the Collectors

The mean number of oyster spat was significantly higher on the oyster-shell, tile and tire collectors (up to $2040.9 . \mathrm{m}^{-2}, 1886.8 . \mathrm{m}^{-2}$ and $762.8 . \mathrm{m}^{-2}$ respectively), mainly at the sites with higher salinities, such as those with the mussel long-lines on Coqueiro Beach, in Anchieta (P5) and on Meio (P6) and Cabrito Islands (P7) (Kruskal-Wallis: $\mathrm{H}=10.01 ; 3$ d.f.; $\mathrm{p}<$ 0.05; Nemenyi test: oyster shell $=$ tile $\geq$ tire $\geq$ PET). The collector made of PET bottle material always had the lowest number of spat (usually with less than 10 spat per collector) (Fig. 3). On the other hand, the oyster collectors were those that attracted the highest quantity of fouling organisms, such as barnacles Balanus sp. or the algae Ulva fasciata or Enteromorpha sp., which prevent spat recruitment. These fouling species also occurred on other collectors, though in lesser quantities. Many collectors were lost during winter time due to storms, but some also in summer as a result of theft or strong winds, mainly at P5 and P7, on the mussel long-lines, more exposed to both these latter factors.

Oyster recruitment occurred throughout the year, being higher from November to February, but because of missing collectors (as explained above) this was not statistically significant (Kruskal-Wallis: $\mathrm{H}=1.42 ; 7$ d.f.; $\mathrm{p}>0.05$ ) (Fig. 4). April and June also had high numbers of spat, but only at sites with higher salinities; in November and December spat also settled at internal estuarine sites such as P1, P3 and P4. The number of oyster spat was positively correlated with the salinity $\left(\rho_{\mathrm{s}}=0.331 ; 39\right.$ d.f.; $\left.\mathrm{p}<0.05\right)$ and with the water temperature $\left(\rho_{s}=0.48 ; 39\right.$ d.f.; $\left.p<0.05\right)$; there was no correlation with the other parameters of the water $(\mathrm{p}>0.05)$.

The mean height of the spat showed great variations; the minimum mean values for the four collectors occurred in December/2004 (when a great number of small spat of around $1 \mathrm{~mm}$ were recorded), and the maximum in February/2005, except for that of the PET collectors which occurred in April/2005. Spat height ranged from $2.9( \pm 2.9)$ to $14.7( \pm 2.9) \mathrm{mm}$ on PET collectors, $4.7( \pm 4.8)$ to $14.3( \pm 6.7) \mathrm{mm}$ on tire collectors, $4.9( \pm 4.4)$ to $15.5( \pm 6.8) \mathrm{mm}$ on tile and 5.6 $( \pm 5.1)$ to $12.8( \pm 5.2) \mathrm{mm}$ on shell collectors (Fig. 5). Considering all the spat recruited, the mean height was $9.99( \pm 4.49) \mathrm{mm}$. All the means had great standard deviations, reflecting the great disparity among spat heights, that varied from 1 to $34 \mathrm{~mm}$; the bigger spat were registered on the tire and tile collectors, probably due to the larger surface areas of these collectors.

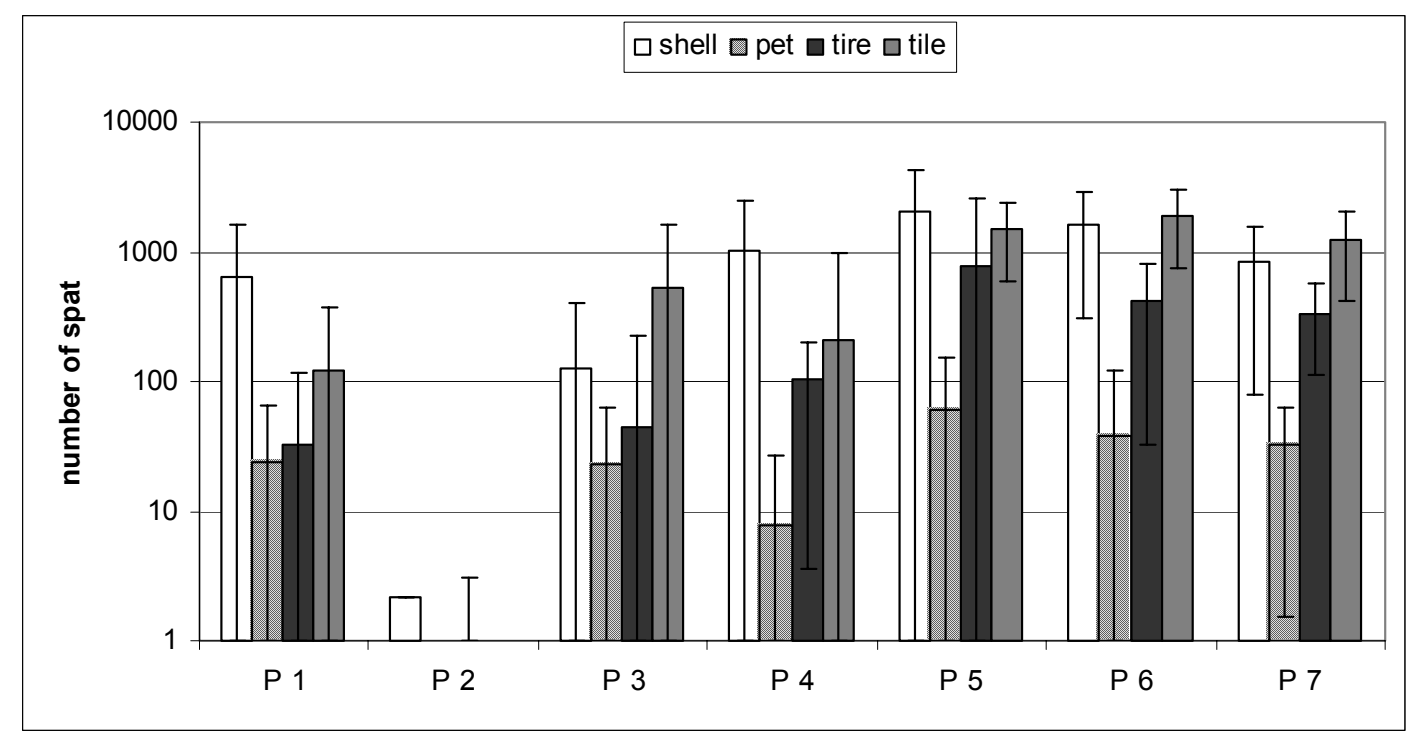

Fig. 3. Mean number of oyster spat. $\mathrm{m}^{-2}$ (log scale) recruited on collectors made of oyster shells, PET bottles, car tire and tiles, in different sites at Benevente river estuary and Piúma islands. Vertical bars exhibit standard deviation. 


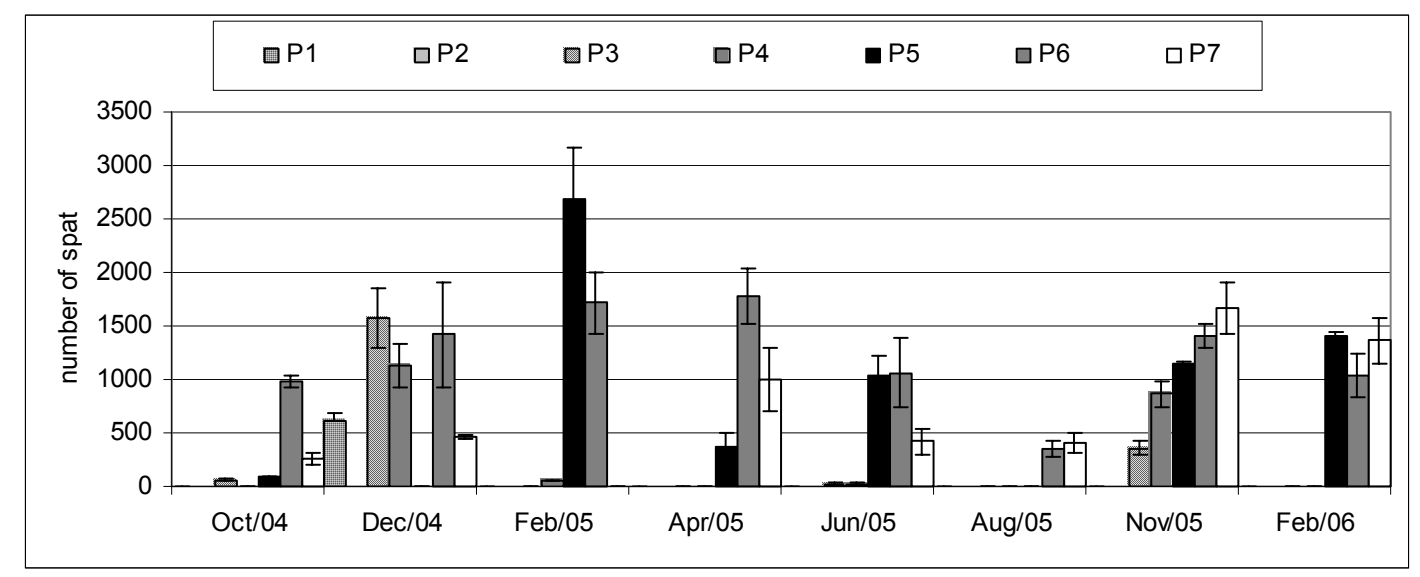

Fig. 4. Mean number of oyster spat. $\mathrm{m}^{-2}$ recruited on collectors from October/2004 to February/2006, in different sites at Benevente river estuary (P1 to P5) and Piúma islands (P6 and P7). Vertical bars exhibit standard deviation.

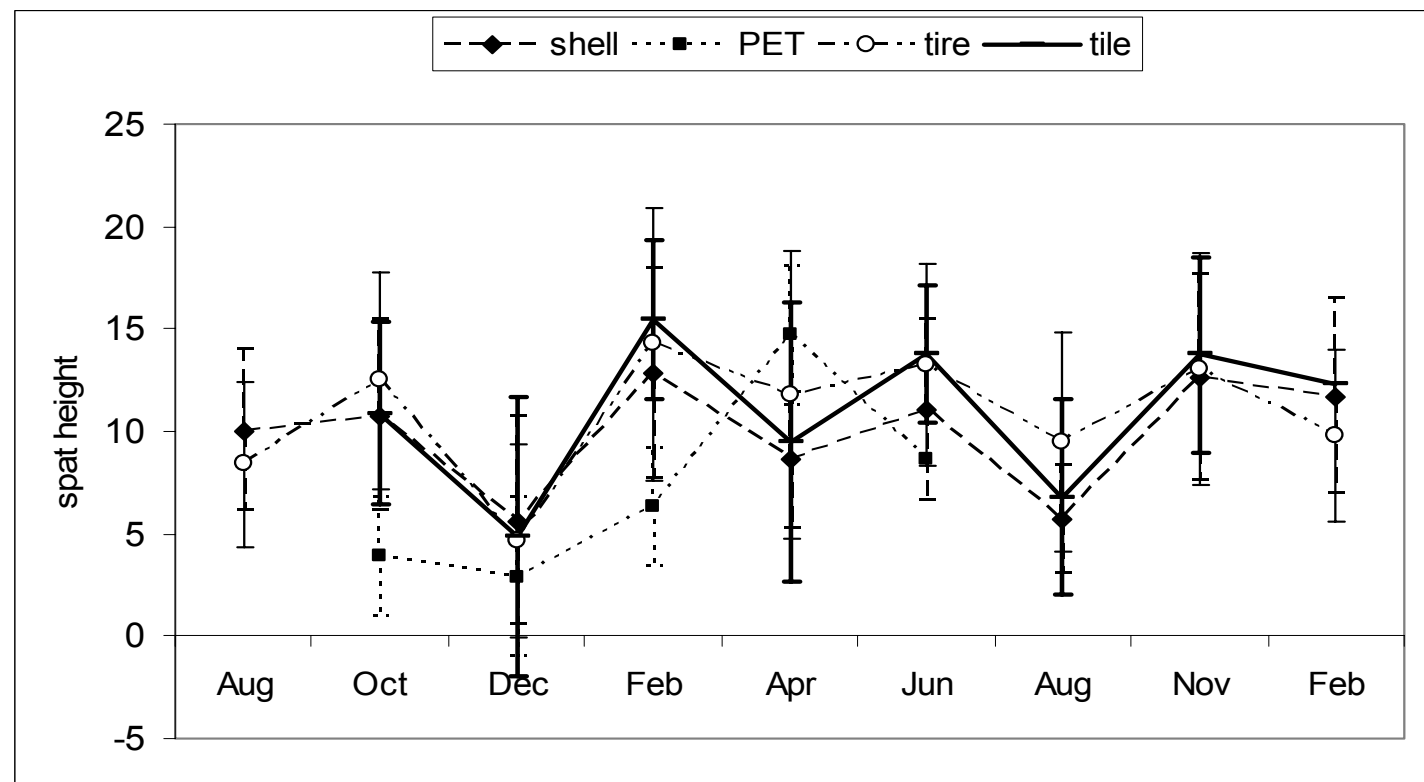

Fig. 5. Mean shell height (mm) of oyster spat recruited on collectors from Aug/2004 to February/2006, in different collectors and sites at Benevente river estuary and Piúma islands. Vertical bars are the standard deviations.

\section{Discussion}

The collectors made of oyster shells and tile were the most efficient in collecting oyster spat; the PET collectors were the least efficient, in spite of their large surface areas. It is possible that the smooth surface of the PET plastic inhibited larval settlement, as verified by DEVAKIE and ALI (2002). These results differ from those of other authors, who have observed high recruitment on PET bottle collectors
(BEZERRA; FRAGA; SILVA, 2003; BUITRAGO; ALVARADO, 2005), contrasting with our results, with very few spat on this type of collector. PET collectors, as well as other plastic collectors (WELDER, 1980; MONTOYA; MADRIZ, 1986), have as a major advantage the ease of spat removal due to the flexibility of the plastic, besides being a recyclable material (BEZERRA; FRAGA; SILVA, 2003; BUITRAGO; ALVARADO, 2005). But both on tile and tire collectors, oyster spat of over $20 \mathrm{~mm}$ can 
be easily removed and this can be done after three months of immersion of the collector (personal observation). MONTOYA and MADRIZ (1986) also recommended the removal of spat from fibre-glass and resin after 3 months, when the spat attached have an inferior shell hard enough to avoid breakage or injury to the oyster's shell. The removal of spat from oystershell collectors, however, imposes limitations on the use of this type of collector (BUITRAGO; ALVARADO, 2005), making the oysters produced suitable only for the oyster meat market, restricted to Brazilian customers, who prefer to consume oysters in their shells (NASCIMENTO; PEREIRA, 2004).

The spat recruitment was observed during all the months sampled, but it was greater in late spring, the summer months and early autumn, mainly in areas of higher salinities, which were better for spat recruitment. Unfortunately, the small number of collectors (due to logistic constraints) limits the validity of this statement, though other authors also have observed that oyster spawning occurs throughout the year, and that the spring and summer months are better for spat recruitment (MONTOYA; MADRIZ, 1986; GALVÃO et al., 2000; BUITRAGO; LUNAR; MORENO , 2002).

Crassostrea oysters are euryhaline and eurythermic (ABSHER, 1987), and can survive drastic changes in salinities and temperatures with no physiological injury, but both parameters have great influence on spawning. NASCIMENTO; PEREIRA (2004) pointed out that, at low salinities (below 8\%o), oysters close their shells and do not filter, which might explain the low number of spat at our estuarine sites. This could also be the reason for the mortality of some spat, observed in February and April, when salinities fell to lethal values in the estuarine areas, due to abnormally high rainfall (pers. obs.). MIRANDA and GUZENSKI (1999) established that the best salinity for spat from hatchery production is from $25-30 \%$, but LEMOS et al. (1994) stated that young larvae survive and grow better at salinities from 25 to $40 \%$, and that natural populations of Crassostrea rhizophorae are well adapted to salinity variations though not to extremes of temperature.

The majority of spat were attached to the lower side of the collectors. This may have been because there was less accumulation of suspended particles than on their upper side (BUITRAGO; ALVARADO, 2005). Further, the pediveliger oyster larvae have negative phototropism (the tendency of the larva to retreat from the light) inducing its settlement on protected and shady substrates (BAKER, 1997). MONTOYA and MADRIZ (1986) stated that the colour and design of spat collectors determine larval settlement and that internal areas are the most suitable. The external areas were more vulnerable to fouling species such as the barnacle Balanus sp. or the algae
Ulva fasciata or Enteromorpha sp., which prevent spat recruitment in our study area.

Among the fouling species there was another oyster spat, Ostrea equestris, of no commercial value due to its small size, but very similar to $C$. rhizophorae (QUEIROZ; SILVEIRA JR., 1990). It can be distinguished (with an optical device) from the C. rhizophorae spat by the small crenulations on its lateral margins near the umbo (whereas $C$. rhizophorae is smooth) (RIOS, 1994), but commercial farmers could fail to distinguish them. To avoid this, spat should be removed from collectors after attaining a height of 20-25 mm, which occurs after three months in $C$. rhizophorae but not in $O$. equestris, a slow growing species.

We concluded that the best place to collected oyster spat is in high salinity areas, close to estuaries (such as P5, P6 and P7), where salinity is more stable and fluctuations in rainfall do not affect or have little influence on spat growth. However, these high salinity areas are not the most suitable places for rearing oysters, seeing that better growth can be attained in lower salinities, such as the internal areas of estuaries (also observed by PEREIRA; AKABOSHI; SOARES, 1988). To avoid lethal falls in salinity, we recommend that collectors be placed in the water from October to December (to collect spat during the rainy months) in high salinity areas, and that they be transferred to areas of low salinity as from April, to avoid the rainy season at estuarine sites.

Regarding the costs, all the collectors utilized in this study can be made from recycled materials, thus lowering the costs for small farmers. Besides this, the recycling of the collectors could pose another advantage, as the remains of calcium deposits on the collectors not only produce a rough surface but also serve as an attractant to the oyster larvae for gregarious setting (DEVAKIE; ALI, 2002).

\section{ACKNOWLEDGEMENTS}

This study was supported by the CNPq (Grant $\mathrm{n}^{\mathrm{o}}$ 503925/03-9) and PIBIC-UFES with a scholarship to the second and fourth authors (6 months each). The authors' thanks are due to the staff of the Fishery and Environmental Council of Anchieta City Hall - ES (SEMP and SEMA) and to the Mariculture Association of Anchieta/ES (AMA), especially to Rildo Costa, Pedro G. Silva, Valdeir Z. Freire and Élson Rui M. Silva, as also to the Fishery School of Piúma- ESCOPESCA staff, mainly to Prof. Sebastião V. Oliveira, and also to its former principal, Nelson W. X. Silva, and the present principal, Jonacir X. Garcindo, for the logistic support provided during field work. We also thank Genyess Vieira, Fabíola dos Reis, Valdirene Aguiar and Larissa Salles for their 
help with the field work, and Dr. Gilberto F. Barroso for the map and suggestions made during the project.

\section{REFERENCES}

ABSHER, T. M. A ostra do mangue no complexo Baía de Paranaguá. Simpósio de Ecossistemas da Costa Sul e Sudeste Brasileira. Publções ACIESP, n. 54-2, p. 143147, 1987.

BAKER, P. Settlement site selection by oyster larvae, Crassostrea virginica: evidence for geotaxis. J. Shellfish Res., v. 16, p. 125-128, 1997.

BEZERRA JR., J. C.; FRAGA, R. T.; SILVA, A.C.C.D. Tecnologia de produção de sementes de ostras nativas, Crassostrea sp. no estuário do Rio São Francisco-SE. In: CONGRESSO BRASILEIRO DE ENGENHARIA DE PESCA, 2003. Porto Seguro, BA. Proceedings, 2003.

BUITRAGO, E.; LUNAR, K.; MORENO, P. Cultivo piloto de la ostra de mangle Crassostrea rhizophorae (Guilding, 1828) en la Laguna de La Restinga, Isla de Margarita. Mem. Fund. La Salle Cien. Nat., v. 154, p. 21-34, 2002

BUITRAGO, E.; ALVARADO, D. A highly efficient oyster spat collector made with recycled materials. Aquacult. Engng, v. 33, p. 63-72, 2005.

DEVAKIE, M .N.; ALI, A. B. Effective use of plastic sheet as substrate in enhancing tropical oyster (Crassostrea iredalei Faustino) larvae settlement in the hatchery. Aquaculture, v. 212, p. 277-287, 2002.

GALVÃO, M. S.; PEREIRA, O. M.; MACHADO, I. C. HENRIQUES, M. B. Aspectos reprodutivos da ostra Crassostrea brasiliana de manguezais do estuário de Cananéia, SP $\left(25^{\circ} \mathrm{S} ; 48^{\circ} \mathrm{W}\right)$. Bolm Inst. Pesca, v. 26, p. 147-162, 2000.

HICKMAN, R. W. Mussel cultivation. In: GOSLING, E. (Ed.). The mussel Mytilus: ecology, physiology, genetics and culture. Amsterdam: Elsevier Science Publ p. 465-510, 1992.

IGNACIO, B. L.; ABSHER, T. M.; LAZOSKI, C.; SOLÉCAVA, A. M. Genetic evidence of the presence of two species of Crassostrea (Bivalvia: Ostreidae) on the coast of Brazil. Mar. Biol., v. 136, p. 987-991, 2000.

JEFFREY, S. W.; HUMPHREY, G. F. New spectrophotometric equations for determining chlorophylls $\mathrm{a}, \mathrm{b}, \mathrm{c}_{1}$ and $\mathrm{c}_{2}$ in higher plants, algae and natural phytoplankton. Biochem. Physiol. Pfl., v. 167, p. 191-194, 1975.

JOSEPH, M. M.; JOSEPH, S. J. 1983. Some aspects of experimental culture of the oyster Crassostrea madrensis (Preston). In: SYMPOSIUM COASTAL AQUACUlTURE, 1983. Proceedings, v. 2, p. 451-455, 1983.

LEMOS, M. B. N.; NASCIMENTO, I. A.; ARAÚJO, M. M. S.; PEREIRA, S. A.; BAHIA, I.; SMITH, D. H. The combined effects of salinity, temperature, antibiotic and aeration on larval growth and survival of the mangrove oyster, Crassostrea rhizophorae. J. Shellfish Res., v.13, p. 187-192, 1994.
MIRANDA, M.B.B.; GUZENSKI, J. Cultivo larval da ostra do mangue, Crassostrea rhizophorae (Guilding, 1828), em diferentes condições de temperatura, salinidade e densidade. Arq. Ciên. Mar, Fortaleza, v. 32, p. 73-84, 1999.

MONTOYA, J. A.; MADRIZ, E. Z Cultivo de Crassostrea rhizophorae (Bivalvia: Ostreidae). I: El uso de la lámina para techo como colector de "semillas". Rev. Lat-amer. Acuicult., Lima-Peru, v. 28, p. 29-32, 1986.

NASCIMENTO, I. A. Cultivo de ostras no Brasil: problemas e perspectivas. Cienc. Cult., Maracaibo, v. 35, p. 871$876,1982$.

NASCIMENTO, I. A. Crassostrea rhizophorae (Guilding) and $C$. brasiliana (Lamarck) in South and Central America. In: MENZEL, W. (Ed.). Estuarine and marine bivalve mollusk culture. Boston: CRC Press. p.125-134, 1991.

NASCIMENTO, I.A.; PEREIRA, S. A. Cultivo da ostra de mangue Crassostrea rhizophorae (Guilding 1828). In: POLI, C. R.et al. (Eds.). Aqüicultura. Florianópolis: Multitarefa Editora. p. 267-288, 2004.

PARK, B.; PARK, M. S.; KIM, B.Y.; HUR, S. B.; KIM, S. J. 1988. Culture of the Pacific oyster (Crassostrea gigas) in the Republic of Korea. National Fisheries Research and Development Agency, Pusan, Republic of Korea, 1983.

PEREIRA, O. M.; AKABOSHI, S.; SOARES, F. C. Cultivo experimental de Crassostrea brasiliana (Lamarck, 1819) no canal da Bertioga, São Paulo, Brasil (23⒌'30"S, $45^{\circ} 13^{\prime} 42^{\prime \prime W)}$. Bolm Inst. Pesca, v. 151, p. 55-65, 1988.

QUEIROZ, C.; SILVEIRA JR., N. Cultivo de ostras. Florianópolis: ACARESC. 24p., 1990.

RIOS, E. 1994. Seashells of Brazil. $2^{\text {nd }}$ ed. Rio Grande: Editora da FURG. 492p., 1994.

ROBERT, R.; GÉRARD, A. Bivalve hatchery technology: the current situation for the Pacific oyster Crassostrea gigas and the scallop Pecten maximus in France. Aquat. Living Resour., v. 12, p. 121-130, 1999.

SATYANARAYANA, K. Observations on the settling of spat and growth of Crassostrea madrensis in Vaigai Estuary at Athankarai. In: SYMPOSIUM COASTAL AQUACULTURE, 1983. Proceedings 2, p. 436-443, 1983.

WELDER, E. 1980. Experimental spat collecting and growing of the oyster, Crassostrea rhizophorae Guilding, in the Cienaga Grande de Santa Marta, Colombia. Aquaculture, v. 21, p. 251-259, 1980.

ZAR, J. H. 1999. Biostatistical analysis. $4^{\text {th }}$. Ed. Upper Saddle River, NJ: Prentice Hall. 918p., 1999.

(Manuscript received 30 March 2007; revised 15 August 2007; accepted 14 April 2008) 